\title{
Genes implicated in multiple sclerosis pathogenesis from consilience of genotyping and expression profiles in relapse and remission
}

\author{
Ariel T Arthur*1, Patricia J Armati ${ }^{1}$, Chris Bye ${ }^{3}$, Southern MS Genetics \\ Consortium $^{4}$, Robert NS Heard ${ }^{2}$, Graeme J Stewart ${ }^{2}$, John D Pollard ${ }^{1}$ and \\ David R Booth ${ }^{2}$
}

\begin{abstract}
Address: ${ }^{1}$ Department of Medicine and the Nerve Research Foundation, the University of Sydney, Sydney, Australia, ${ }^{2}$ Institute for Immunology and Allergy Research, Westmead Millennium Institute, Sydney, Australia, ${ }^{3}$ Westmead Millenium Institute, Sydney, Australia and ${ }^{4}$ The University of Melbourne, Melbourne, Australia

Email: Ariel T Arthur* - ariela@med.usyd.edu.au; Patricia J Armati - armati55@med.usyd.edu.au; Chris Bye - cbye@hfi.unimelb.edu.au; Southern MS Genetics Consortium - rubio@hfi.unimelb.edu.au; Robert NS Heard - heard@idx.com.au;

Graeme J Stewart - stewartg@westgate.wh.usyd.edu.au; John D Pollard - jdpoll@med.usyd.edu.au;

David R Booth - davidb@westgate.wh.usyd.edu.au

* Corresponding author
\end{abstract}

Published: 19 March 2008

BMC Medical Genetics 2008, 9:17 doi:10.1 186/1471-2350-9-17

This article is available from: http://www.biomedcentral.com/147I-2350/9/17

(C) 2008 Arthur et al; licensee BioMed Central Ltd.

This is an Open Access article distributed under the terms of the Creative Commons Attribution License (http://creativecommons.org/licenses/by/2.0), which permits unrestricted use, distribution, and reproduction in any medium, provided the original work is properly cited.
Received: 25 July 2007

Accepted: 19 March 2008

\footnotetext{
Abstract

Background: Multiple sclerosis (MS) is an inflammatory demyelinating disease of the central nervous system (CNS). Although the pathogenesis of MS remains unknown, it is widely regarded as an autoimmune disease mediated by T-lymphocytes directed against myelin proteins and/or other oligodendrocyte epitopes.

Methods: In this study we investigated the gene expression profiles of peripheral blood cells from patients with RRMS during the relapse and the remission phases utilizing gene microarray technology. Dysregulated genes encoded in regions associated with MS susceptibility from genomic screens or previous trancriptomic studies were identified. The proximal promoter region polymorphisms of two genes were tested for association with disease and expression level.

Results: Distinct sets of dysregulated genes during the relapse and remission phases were identified including genes involved in apoptosis and inflammation. Three of these dysregulated genes have been previously implicated with MS susceptibility in genomic screens: TGF $\beta$ I, CD58 and DBCI. TGF $\beta$ I has one common SNP in the proximal promoter: $-508 \mathrm{~T}>\mathrm{C}$ ( $\mathrm{rs}$ |800469). Genotyping two Australian trio sets (total 620 families) found a trend for over-transmission of the T allele in MS in females $(p<0.13)$. Upregulation of $\mathrm{CD} 58$ and $\mathrm{DBCl}$ in remission is consistent with their putative roles in promoting regulatory $T$ cells and reducing cell proliferation, respectively. A fourth gene, ALOX5, is consistently found over-expressed in MS. Two common genetic variants were confirmed in the ALOX5 putatve promoter: $557 \mathrm{~T}>\mathrm{C}$ ( $\mathrm{rs}$ / 2762303) and a 6 bp tandem repeat polymorphism (GGGCGG) between position - 147 and - 176; but no evidence for transmission distortion found.

Conclusion: The dysregulation of these genes tags their metabolic pathways for further investigation for potential therapeutic intervention.
} 


\section{Background}

MS the most common cause of chronic neurological disability in young adults with a lifetime risk of one in 400 in northern Europeans [1]. Most patients have the relapsingremitting (RR) form of MS characterised by episodes of neurologic impairment followed by complete or almost complete recovery [2]. A relapse is thought to be caused by some trigger of the immune system resulting in the trafficking of activated, myelin-reactive T-cells into the CNS through a disrupted blood brain barrier (BBB) causing acute inflammation. Early clinical symptoms result from oligodendrocytic damage and/or demyelination. The regression of symptoms is attributed to resolution of immune-based attack and associated oedema and to partial remyelination or redistribution of sodium channels along demyelinated segments of axons [3]. Relapses may be mild or severe with exacerbations lasting several days to several weeks, or even months.

We aimed to investigate the gene expression profiles of whole blood from RRMS patients during the relapse and the remission phases utilizing gene microarrays and RTPCR for confirmation of results. Whilst obtaining RNA samples for microarray analysis from brain tissue is problematic, peripheral blood is an appropriate tissue to study since it is the trafficking compartment of cells of the immune system and provides insight into the specific components that may be driving the immune response, contributing to both the disease and its exacerbations in RRMS. We used this transcriptomic information to find dysregulated genes, and then combined this with genetic association data linking genomic regions with $\mathrm{MS}$, to find dysregulated genes encoded in genomic regions associated with MS. Since genomic studies have confirmed that genes are often regulated by their 5 ' untranslated regions $[4,5]$, we then sought polymorphisms in these regions and tested them for association with MS.

We used four key approaches in our study. First, since demyelination is probably due largely to leukocytes in the peripheral circulation, and much of the variation in leukocyte expression is genetically controlled; we investigated the mRNA profiles of peripheral blood cells using whole blood rather than just mononuclear cells. Secondly, since many mRNA species are short-lived and subject to nucleases, blood was collected directly into a solution which immediately halts transcription and mRNA degradation. Thirdly, we recruited patients in remission who were not receiving immunomodulatory treatments and who had experienced 1-2 relapses within 2 years prior to blood sampling to ensure a patient cohort with a similar disease course and severity. Patients undergoing relapse were sampled on admission to hospital and prior to receiving any steroid treatment for their relapse. Finally, because aberrant gene expression may be an effect of MS rather than a cause, we investigated genetic differences in gene promoter regions, which would suggest inherited factors as a cause for the gene dysregulation.

Studies on gene expression signatures in MS from cells have indicated upregulation of pro-inflammatory, antiapoptotic pathways [6]. Earlier, we found evidence of differences in gene expression between the progressive forms of the disease, primary progressive (PPMS) and secondary progressive MS [7], and by using the transcriptomic/ genomic approach identified a CD127 haplotype associated with PPMS. The association of this gene with MS has now been widely replicated [8-10]. Here we use the same approach, and so identify TGF $\beta 1$, CD58 and DBC1 as implicated in MS pathogenesis. These and other identified dysregulated genes suggest the involvement of genes regulating the immune system and apoptosis in MS. Further, one gene in particular, ALOX5, is upregulated in previous studies $[7,11]$, and in both our relapse and remission cohorts.

\section{Methods \\ Patient and control blood samples \\ Gene expression}

Blood samples from RRMS patients were collected at the MS Society Australia Clinic, or upon admittance to the Institute of Clinical Neuroscience, at Royal Prince Alfred Hospital, Sydney, NSW Australia. All patients recruited for this study were assessed independently by a neurologist who diagnosed a clinical relapse, in the case of the relapsing cohort, or confirmed clinical remission of the patients in the remission cohort. Blood samples were taken from relapsing patients prior to immunomodulatory treatment, whilst patients in remission were not receiving treatment and had experienced 1-2 relapses in the 2 years prior to blood sampling. Relapsing patients were between 30-66 years of age with a male to female ratio of $5: 5$, remission patients were between 30-55 years of age with a male to female ratio of 4:6. Control human blood samples were obtained from staff at Westmead Hospital, NSW Australia. The control individuals were Caucasian and between 2055 years of age with a male to female ratio of 5:20. Female control RNA samples were pooled to obtain a single control sample. All blood samples (15 mls total) were numerically coded and obtained after informed consent according to the University of Sydney Human Ethics (protocol number 02/03/17) and the Central Sydney Area Health Service (CSAHS) Ethics (protocol number X020328).

\section{DNA sequencing}

Genomic DNA pools used for promoter region sequencing were constructed by the Institute for Immunology and Allergy Research. Genomic DNA samples from 217 HLADR2 positive MS patients, 155 HLA-DR2 negative MS 
patients, 169 probands from MS multiplex families, and from 187 unrelated healthy controls were pooled separately using the Ban et al protocol [12], based on previously described methods [13].

\section{Genotyping}

Trio families (MS patient, mother and father) used for genotyping were recruited by the Institute for Imunology and Allergy Research.

\section{RNA extraction}

All whole blood samples were collected under standard phlebotomy protocol into PAXgene tubes (PreAnalytix, Switzerland) and RNA extracted from the samples using the PAXgene Blood RNA Kit (PreAnalytix, Switzerland). All methods followed the protocols supplied in the kit [14].

\section{RNA preparation for microarray analysis}

The MessageAmp II Kit [15] was used to amplify the RNA for use with $10.5 \mathrm{~K}$ Peter MacCallum microarrays. These comprise $\sim 10,500$ elements representing 9,381 unique cDNAs (Unigene Build 144) and were printed onto superamine slides (Telechem) using a robotic arrayer (Virtek) by The Peter MacCallum Cancer Institute, Australia - full gene list published on the author's website [16]. The SuperScript Indirect cDNA Labelling System (Invitrogen) was used for cDNA production and CyDye (Amersham Biosciences) labeling. The protocol supplied was followed [17]. The labeled CDNA was hybridized at $65^{\circ} \mathrm{C}$ overnight, the arrays were washed and scanned using a 4000B scanner (AXON Instruments), then visualized using GenePix Pro 5.0 software. Each microarray was repeated using alternate CyDye combinations so that there were 2 arrays per patient. Each MS sample was compared to the female reference (pool of 20 females). Male controls were compared to this same reference. Genes different between the male controls and female reference were considered 'sex-specific' and excluded from the analysis of MS samples versus the reference sample.

\section{Microarray data analysis}

Raw data files generated by the GenePix Pro software were loaded into the program R [18] and normalized using the freely available microarray analysis package Limma [18]. The data was normalized using the print-tip loess method and all spots with an intensity value less than 100 were filtered out of the data sets as these were considered unreliable. To avoid type 2 errors (false rejection of association) we used the Significance Analysis of Microarrays (SAM) package [19], which uses modified t tests to compare results for each gene and uses an iterative procedure to evaluate the likelihood of the association occurring by chance. The SAM package was used in conjunction with Limma to identify the most statistically significant dysreg- ulated genes. The GOstat program [20] was used to identify gene ontology groups which were highly represented in the dysregulated gene sets.

\section{Quantitative real-time PCR}

All primers were designed using Primer3 [21]. ALOX5 (H51574) forward primer sequence: 5'-CCACGGGGACTACATCGAGTT-3' and reverse primer sequence: 5'-CTTTACGTCGGTGTTGCTTGAG-3'. TGF $\beta 1$ (R36467) forward primer sequence: 5'-CGAGCCTGAGGCCGACTACTA-3' and reverse primer sequence: 5'-CTCGGAGCTCTGATGTGTTGAA-3'.

All RNA samples were quantified using RiboGreen reagent (Molecular Probes, Eugene, OR, USA) and fluorescence measured using a FluoroCount fluorescence microplate reader (Packard Bioscience, Meriden, CT, USA). Patient and control pool RNA was reverse-transcribed into cDNA by preparing $20 \mu \mathrm{l}$ reverse transcription reaction containing: 500 ng RNA, $250 \mu \mathrm{g}$ Oligo dT (Promega, Madison, WI, USA), $10 \mathrm{mM}$ dNTPs (Promega, Madison, WI, USA). The reaction was incubated at $65^{\circ} \mathrm{C}$ for $5 \mathrm{~min}$ and cooled on ice, then $5 \times$ buffer (Promega, Madison, WI, USA), 40 U RNase inhibitor (Promega, Madison, WI, USA), and $400 \mathrm{U}$ reverse transcriptase (Promega, Madison, WI, USA) was added and the reaction incubated at $42^{\circ} \mathrm{C}$ for $60 \mathrm{~min}$ then $80^{\circ} \mathrm{C}$ for $15 \mathrm{~min}$.

SYBR Green (Applied Biosystems Foster City, CA, USA) was used to quantify cDNA by real-time PCR. The PCR reaction contained CDNA derived from $5 \mathrm{ng}$ of MS or control total RNA, SYBR Green master mix (Applied Biosystems Foster City, CA, USA), and 100 ng of each primer. The reaction was amplified in a Corbett Rotor-Gene 2000 real-time PCR cycler (Corbett Research, NSW, Australia) using the following cycling profile: 1 cycle of $95^{\circ} \mathrm{C}$ for 10 min; 5 cycles $\left(95^{\circ} \mathrm{C}\right.$ for $30 \mathrm{~s}, 64^{\circ} \mathrm{C}$ for $30 \mathrm{~s}, 72^{\circ} \mathrm{C}$ for $\left.30 \mathrm{~s}\right)$; 35 cycles $\left(95^{\circ} \mathrm{C}\right.$ for $30 \mathrm{~s}, 60^{\circ} \mathrm{C}$ for $30 \mathrm{~s}, 72^{\circ} \mathrm{C}$ for $\left.30 \mathrm{~s}\right)$; then $72^{\circ} \mathrm{C}$ for $5 \mathrm{~min}$. Melt curve analysis was then performed between $75-99^{\circ} \mathrm{C}$ in $1^{\circ} \mathrm{C}$ increments. RT-PCR products were electrophoresed on $2 \% 1 \times$ TBE agarose gels, stained with ethidium bromide $(0.5 \mu \mathrm{g} / \mathrm{ml})$ to visualize the product. Normalization to total RNA, or the $2^{-\Delta \mathrm{Ct}}$ method [22] was used to determine differences in expression between the MS individuals and the control pool.

\section{Promoter region sequencing}

Genomic DNA pools consisting of DNA samples from 217 HLA-DR2 positive MS patients, 155 HLA-DR2 negative MS patients, 169 probands from MS multiplex families, and from 187 unrelated healthy controls were used for promoter region sequencing. PCR primers were designed to amplify the $5^{\prime}$ untranslated promoter region (approximately 500 bp upstream of the $1^{\text {st }}$ exon) using Primer3 [20]. ALOX5 (H51574) forward primer 
sequence: 5'-AGCCTCTGTGCTCCAGAATC-3' and reverse primer sequence: 5'-GGCTGAGGTAGATGTAGTCGTCA3'. TGFß1 (R36467) forward primer sequence: 5'GGGAGGTGCTCAGTAAAGG-3' and reverse primer sequence: 5'-CTCGCTGTCTGGCTGCTC-3'. PCR reactions were prepared using $2 \times$ PCR Mastermix (MBI Fermentas, Vilinus, Lithuania), $100 \mathrm{ng}$ of each PCR primer and $50 \mathrm{ng}$ of pooled DNA samples or $0.1-1 \mu \mathrm{g}$ of control individual genomic DNA. Reactions were amplified in the Mastercycler thermocycler (Eppendorf AG, Hamburg, Germany) using the following $64^{\circ}-60^{\circ} \mathrm{C}$ "touchdown" temperature profile: 1 cycle of $95^{\circ} \mathrm{C}$ for $2 \mathrm{~min} 30 \mathrm{~s}$; then 5 cycles $\left(95^{\circ} \mathrm{C}\right.$ for $30 \mathrm{~s}, 64^{\circ} \mathrm{C}$ for $30 \mathrm{~s}, 72^{\circ} \mathrm{C}$ for $30 \mathrm{~s}$ ), then 30 cycles of $\left(95^{\circ} \mathrm{C}\right.$ for $30 \mathrm{~s}, 60^{\circ} \mathrm{C}$ for $30 \mathrm{~s}, 72^{\circ} \mathrm{C}$ for $\left.30 \mathrm{~s}\right)$; then 1 cycle of $72^{\circ} \mathrm{C}$ for $5 \mathrm{~min}$. For GC-rich sequences in the ALOX5 and TGF $\beta 1$ promoter regions, 5\% DMSO and $0.02 \mathrm{U} / \mu \mathrm{l}$ Phusion DNA polymerase (Finnzymes, Finland) was also added to the reaction and a $62^{\circ}-58^{\circ} \mathrm{C}$ "touchdown" temperature profile with a $98^{\circ} \mathrm{C}$ denaturation temperature, was used: 1 cycle of $98^{\circ} \mathrm{C}$ for $2 \mathrm{~min} 30 \mathrm{~s}$; then 5 cycles $\left(98^{\circ} \mathrm{C}\right.$ for $30 \mathrm{~s}, 62^{\circ} \mathrm{C}$ for $30 \mathrm{~s}, 72^{\circ} \mathrm{C}$ for $\left.30 \mathrm{~s}\right)$, then 30 cycles of $\left(98^{\circ} \mathrm{C}\right.$ for $30 \mathrm{~s}, 58^{\circ} \mathrm{C}$ for $30 \mathrm{~s}, 72^{\circ} \mathrm{C}$ for $\left.30 \mathrm{~s}\right)$; then 1 cycle of $72^{\circ} \mathrm{C}$ for $5 \mathrm{~min}$. PCR products were electrophoresed on $2 \% 1 \times \mathrm{TBE}$ agarose gels, stained with ethidium bromide $(0.5 \mu \mathrm{g} / \mathrm{ml})$ to visualize PCR products. The PCR products were then purified using $1 \mu$ l Exo-SAPIT (exonuclease I/Shrimp alkaline phosphatase) (USB Corporation, Cleveland, OH, USA) incubated at $37^{\circ} \mathrm{C}$ for $15 \mathrm{~min}$ followed by $80^{\circ} \mathrm{C}$ for $15 \mathrm{~min}$.

Unidirectional DNA sequencing was performed using an ABI Prism Big Dye terminator sequencing kit version 3.0 (Applied Biosystems, Foster City, CA, USA). PCR products were either sequenced in the forward or reverse direction using an internal primer. ALOX5 (H51574) reverse internal primer sequence: 5'-CATCTAGCGCCGCAGC-3'. TGF $\beta 1$ (R36467) forward internal primer sequence: 5'CTCAGTAAAGGAGAGCAATTC-3'. Reactions were incubated at $95^{\circ} \mathrm{C}$ for $5 \mathrm{~min}$, followed by 25 cycles $\left(95^{\circ} \mathrm{C}\right.$ for $30 \mathrm{~s}, 50^{\circ} \mathrm{C}$ for $15 \mathrm{~s}$ and $60^{\circ} \mathrm{C}$ for $\left.4 \mathrm{~min}\right)$. Reactions were then electrophoresed on an ABI PRISM 3100 Genetic Analyzer (Applied Biosystems, Foster City, CA, USA) by the Westmead Millenium Institute DNA Sequencing Facility. DNA sequences were viewed using ABI Prism Editview software (Applied Biosystems, Foster City, CA, USA).

\section{Genotyping}

Up to 388 trio families, recruited by the Institute for Immunology and Allergy Research, were utilized for this genotyping study. Since appropriate matching of controls is essential to avoid false positive associations resulting from population stratification or non-random mating, genetically unrelated family members of the MS patients are usually used as controls. However, confounding due to hidden stratification can still occur. For this reason we have used trio families in this study. When a patient and both parents (a "trio family") are considered, the nontransmitted parental alleles form the controls. In these trio families association was tested using the transmission disequilibrium test (TDT) [23].

One hundred and two trio families were genotyped for the ALOX5 6 bp (GGGCGG) deletion. PCR primers were designed to amplify the transcription factor binding region, containing the repeated motif GGGCGG, using Primer3 [21]. Forward primer: 5'-AGGTCCCGCCCAGTC3' and reverse: 5'GGTCTGGCTCCAGGCT-3'. PCR reactions were prepared using $2 \times$ ImmoMix PCR Mastermix (Bioline), $100 \mathrm{ng}$ of each PCR primer, $0.25 \mu \mathrm{l}$ of $100 \%$ DMSO and $50 \mathrm{ng}$ of DNA samples. Reactions were amplified in the Mastercycler thermocycler (Eppendorf $A G$, Hamburg, Germany) using the following $68^{\circ}-64^{\circ} \mathrm{C}$ "touchdown" temperature profile: 1 cycle of $96^{\circ} \mathrm{C}$ for 10 min; then 5 cycles $\left(96^{\circ} \mathrm{C}\right.$ for $30 \mathrm{~s}, 68^{\circ} \mathrm{C}$ for $30 \mathrm{~s}, 72^{\circ} \mathrm{C}$ for $30 \mathrm{~s})$, then 25 cycles of $\left(96^{\circ} \mathrm{C}\right.$ for $30 \mathrm{~s}, 64^{\circ} \mathrm{C}$ for $30 \mathrm{~s}$, $72^{\circ} \mathrm{C}$ for $30 \mathrm{~s}$ ); then 1 cycle of $72^{\circ} \mathrm{C}$ for $5 \mathrm{~min}$. PCR products were electrophoresed on $15 \%$ acrylamide gels made with: $40 \%$ acrylamide; $10 \times$ TBE buffer; ammonium persulfate $(100 \mathrm{mg} / \mathrm{ml})$; TEMED; and $\mathrm{H}_{2} \mathrm{O}$. The gels were stained with ethidium bromide $(0.5 \mu \mathrm{g} / \mathrm{ml})$ to visualize PCR products. Transmission disequilibrium tests (TDT) were performed using the Haploview program [24].

Three hundred and eighty eight trio families were genotyped for the TGF $\beta 1-508 \mathrm{C}>\mathrm{T}$ SNP. Genotyping of the TGF $\beta 1$ SNP was performed by the Australian Genome Research Facility (AGRF) (Queensland, Australia). The AGRF custom SNP genotyping service utilized the homogenous MassExtend (hME - single base extension) analysed on the Sequenom Autoflex Mass spectrometer and the Samsung 24 pin nanodispensor. SNP assays were designed by AGRF, PCR oligos were obtained and then processed in multiplex format, following PCR, on a mass spectrometer. The mass spectrometer allowed different SNPs to be identified with a high level of sensitivity. Transmission disequilibrium tests (TDT) were performed as above. The same genotyping strategy was employed for an independent cohort of 250 trios collected by Victorian institutions [25].

\section{Results Gene expression in RRMS: microarray vs. RT-PCR Relapse}

The gene expression profile of 10 RRMS patients in clinical relapse compared to the control sample identified 989 statistically significant ( $\mathrm{p} \leq 0.05)$ up-regulated genes. Of particular interest, ALOX5 was up-regulated $2.58( \pm 0.59)$ fold (mean microarray fold change for each individual), whilst the RT-PCR results showed a $3.41( \pm 0.29)$ fold increase (Figure 1). TGF $\beta 1$ was up-regulated by $1.97( \pm$ 


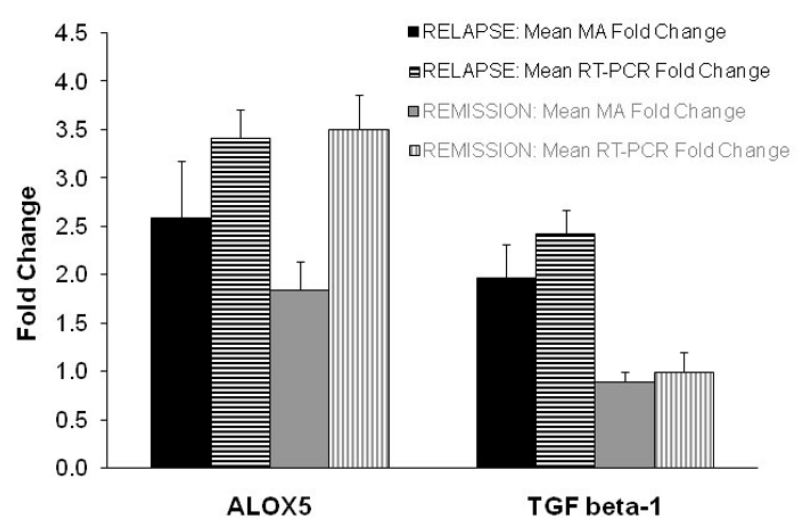

Figure I

Microarray vs RT-PCR results for ALOX5 and

TGF $\beta$ I. ALOX 5 was up-regulated during relapse and remission while TGF $\beta$ I was up-regulated only during the relapse phase.

$0.34)$ according to the mean microarray results and 2.42 $( \pm 0.24)$ according to RT-PCR (Figure 1$)$. In addition, 536 statistically significant ( $\mathrm{p} \leq 0.05)$ genes were down-regulated. The complete dysregulated gene list (obtained from the limma analysis) for the relapse phase can be viewed on the author's website [16].

\section{Remission}

The gene expression profile of 10 RRMS patients in remission compared to the control sample identified 655 statistically significant $(\mathrm{p} \leq 0.05)$ up-regulated genes. ALOX5 was also up-regulated during remission with a mean microarray fold change of $1.84( \pm 0.29)$ and $3.51( \pm 0.36)$ according to RT-PCR (Figure 1). According to the microarray and RT-PCR analysis, TGF $\beta 1$ was not up-regulated in RRMS patients during the remission phase. In addition, 662 statistically significant $(\mathrm{p} \leq 0.05)$ genes were downregulated. The complete dysregulated gene list (obtained from the limma analysis) for the remission phase can be viewed on the author's website [16]. It should be noted that due to the use of whole blood, fold change values of significant differentially expressed genes were relatively small, most around a value of 1.5-2.5.

\section{GO pathways over-represented in the dysregulated gene sets}

Table 1 lists the statistically significant $(\mathrm{p} \leq 0.05)$ over-represented pathways, in the relapse and remission upregulated gene sets, according to the GOstat program. There were no over- or under-represented pathways in the downregulated gene sets for either group. The over-represented pathways in the relapse upregulated gene set were predominantly inflammation/apoptosis-related, whilst the pathways in the remission upregulated gene set were quite distinct, being related instead to protein transport and localization.

\section{Screening dysregulated genes for genomic association with MS}

Prior to 2007, the two largest genomic screens have been that of the GAMES collaborative using > 4000 microsatellite markers in a case controls study [26], and the affected family study using 400 SNPs in 1000 individuals [27]. The latter identified 5q33, 17q23 and 19p13 as having the highest LOD scores of the non-HLA region, and several genes from the most dysregulated set in relapse and remission were encoded in these genomic regions (Table 2). The meta-analysis from the GAMES study found 3 microsatellite markers associated with MS, D11S1986, D19S552, and D20S894. Only 3 genes were encoded within $1 \mathrm{MB}$, the likely maximum linkage distance, of any of these markers: TGF $\beta 1$, CEACAM 1 and the glial maturation factor (all from 19q13.2). Only TGF $\beta 1$ is immune cell specific [28], so this gene was selected for further study. A more recent screen by the international multiple sclerosis consortium (IMSGC), has provided a more comprehensive coverage of the genome [10], and identified 38 genes with primary evidence for association. Of these 4 were dysregulated in our study: CD58, DBC1, TAF1A, and FHIT (Table 2). The genetic association of CD58 and DBC1 were confirmed in the IMSGC's replication study.

\section{Genotyping of the TGF $\beta$ I promoter region}

In the TGF $\beta 1$ promoter sequence, one known SNP at position $-508 \mathrm{~T}>\mathrm{C}$ (rs1800469) was confirmed in both the MS and control populations (Table 3 ). No other previously identified or common novel SNPs were found. This SNP was not associated with MS overall in the Westmead cohort (380 trios), but as there was a trend $(P<0.13)$, and the statistical power may not have been sufficient, we increased the cohort size to 620 trios. However, in the combined cohort there was still no significant association.

\section{Genotyping of the ALOX5 promoter region}

Because the gene association studies do not exclude regions as having associations, we examined the promoter region of ALOX5, which is upregulated in many MS peripheral blood gene expression arrays $[7,11]$, including both the relapse and remission sets here. In the ALOX5 5'UTR sequence, one known SNP at position -557 T>C (rs12762303) was confirmed in both the MS and control populations, in addition to a deletion of one of the $6 \mathrm{bp}$ tandem repeats (GGGCGG) of the consensus Sp1 binding sequence located between position -147 and -176 upstream from the ATG start site of the gene, as identified by In et al [29] (Table 3). This region also contains 5 Egr1 binding motifs, located between position -148 and 180. 
Table I: GO pathways over-represented in the relapse and remission upregulated gene sets.

\begin{tabular}{|c|c|c|c|}
\hline Disease Phase/Expression & Gene Ontology & p-value & Genes \\
\hline \multirow[t]{9}{*}{ RELAPSE Upregulated } & $\begin{array}{l}\text { GO:0009607 - Response to biotic } \\
\text { stimulus }\end{array}$ & 0.0462 & $\begin{array}{l}\text { GPR65, NMI, TAP2, IFII6, CSF2RB, TCRIM, ICOS, FCGR2B, } \\
\text { CD48, BSTI, TNFSFI0, TLR5, MCP, DNAJB6, MNDA, GBP2, } \\
\text { OXSRI, AQP9, TNFAIP6, NFIL3, CD53, GEM, LY96, DOCK2, } \\
\text { ILIB, CLECSF6, PARP4, PLA2G7, CD97, MX2, 5233, HSPAIB, } \\
\text { MAPKI4, ILIR2, C3ARI, IFIT2, STATI, IFNGRI, SI00A8, EDEMI, } \\
\text { LYZ, FAS, HSPAIL, LTBR, ILIRLI, B2M, HSPAIA }\end{array}$ \\
\hline & GO:0008219 - Cell death & 0.0462 & $\begin{array}{l}\text { PARP4, GADD45B, MCLI, BCL2, GPR65, SMNDCI, RAFI, } \\
\text { BIRC2, RAD2I, CASP3, CASPI0, TXNLI, BCLAFI, API5, STATI, } \\
\text { CULI, YWHAG, TNFSFI0, GADD45G, LYZ, FAS, ILIB, TRAF5, } \\
\text { LTBR, TAXIBPI, CASPI, BID }\end{array}$ \\
\hline & GO:0006955 - Immune response & 0.0462 & $\begin{array}{l}\text { GPR65, NMI, TAP2, IFII6, CSF2RB, TCRIM, ICOS, FCGR2B, } \\
\text { BSTI, TNFSFI0, TLR5, MCP, MNDA, GBP2, AQP9, NFIL3, } \\
\text { TNFAIP6, CD53, GEM, DOCK2, LY96, ILIB, CLECSF6, PARP4, } \\
\text { PLA2G7, CD97, MX2, MAPKI4, ILIR2, C3ARI, IFIT2, SI00A8, } \\
\text { FAS, LTBR, ILIRLI, B2M }\end{array}$ \\
\hline & GO:0016265 - Death & 0.0462 & $\begin{array}{l}\text { PARP4, GADD45B, MCLI, BCL2, GPR65, SMNDCI, RAFI, } \\
\text { BIRC2, RAD2I, CASP3, CASPI0, TXNLI, BCLAFI, API5, STATI, } \\
\text { CULI, YWHAG, TNFSFI0, GADD45G, LYZ, FAS, ILIB, TRAF5, } \\
\text { LTBR, TAXIBPI, CASPI, BID }\end{array}$ \\
\hline & GO:0006952 - Defense response & 0.0462 & $\begin{array}{l}\text { GPR65, NMI, TAP2, IFII6, CSF2RB, TCRIM, ICOS, FCGR2B, } \\
\text { CD48, BSTI, TNFSFI0, TLR5, MCP, MNDA, GBP2, AQP9, NFIL3, } \\
\text { TNFAIP6, CD53, GEM, DOCK2, LY96, ILIB, CLECSF6, PARP4, } \\
\text { PLA2G7, CD97, MX2, MAPK I4, ILIR2, C3ARI, IFIT2, SI00A8, } \\
\text { LYZ, FAS, LTBR, ILIRLI, B2M }\end{array}$ \\
\hline & $\begin{array}{l}\text { GO:0004722 - Protein serine/ } \\
\text { threonine phosphatase activity }\end{array}$ & 0.0462 & MTMR6, PPMIA, PPMIB, DUSP6, PPP2R2A, MTMRI \\
\hline & GO:0006915 - Apoptosis & 0.0462 & $\begin{array}{l}\text { GADD45B, MCLI, BCL2, GPR65, SMNDCI, RAFI, BIRC2, } \\
\text { RAD2I, CASP3, CASPI0, TXNLI, BCLAFI, API5, STATI, } \\
\text { YWHAG, CULI, TNFSFI0, GADD45G, FAS, ILIB, TRAF5, LTBR, } \\
\text { TAXIBPI, CASPI, BID }\end{array}$ \\
\hline & $\begin{array}{l}\text { GO:00I250I - Programmed cell } \\
\text { death }\end{array}$ & 0.0462 & $\begin{array}{l}\text { GADD45B, MCLI, BCL2, GPR65, SMNDCI, RAFI, BIRC2, } \\
\text { RAD2I, CASP3, CASPI0, TXNLI, BCLAFI, API5, STATI, } \\
\text { YWHAG, CULI, TNFSFI0, GADD45G, FAS, ILIB, TRAF5, LTBR, } \\
\text { TAXIBPI, CASPI, BID }\end{array}$ \\
\hline & $\begin{array}{l}\text { GO:0005057 - Receptor signaling } \\
\text { protein activity }\end{array}$ & 0.0533 & $\begin{array}{l}\text { STATI, TGFBR2, RAFI, LYN, ACVRIB, MAPKI4, NSMAF, } \\
\text { MAPK9, IRSI, TCRIM, ILIRLI, PDLIM5, MAPK8 }\end{array}$ \\
\hline \multirow[t]{5}{*}{ REMISSION Upregulated } & GO:00I503I- protein transport & 0.0189 & $\begin{array}{l}\text { STXBP3, RANBP6, RAB2, PTTGIIP, ARFI, STX7, SNX2, GRP58, } \\
\text { TLOCI, KPNBI, VDP, SNAGI, CLTC, COPB, TMED7, ARF3, } \\
\text { RAB5A, TNPOI, RABIA, COPA, RAB7, TLKI }\end{array}$ \\
\hline & $\begin{array}{l}\text { GO: } 0045 \text { I } 84 \text { - establishment of } \\
\text { protein localization }\end{array}$ & 0.0189 & $\begin{array}{l}\text { STXBP3, RANBP6, RAB2, PTTGIIP, ARFI, STX7, SNX2, GRP58, } \\
\text { TLOCI, KPNBI, VDP, SNAGI, CLTC, COPB, TMED7, ARF3, } \\
\text { RAB5A, TNPOI, RABIA, COPA, RAB7, TLKI }\end{array}$ \\
\hline & GO:0008104 - protein localization & 0.0189 & $\begin{array}{l}\text { STXBP3, RANBP6, RAB2, PTTGIIP, ARFI, STX7, SNX2, GRP58, } \\
\text { TLOCI, KPNBI, VDP, SNAGI, CLTC, COPB, TMED7, ARF3, } \\
\text { RAB5A, TNPOI, RABIA, COPA, RAB7, TLKI }\end{array}$ \\
\hline & $\begin{array}{l}\text { GO:0005885 - Arp } 2 / 3 \text { protein } \\
\text { complex }\end{array}$ & 0.046 & ARPC2, ACTR3, ARPC3 \\
\hline & $\begin{array}{l}\text { GO: } 0030833 \text { - regulation of actin } \\
\text { filament polymerization }\end{array}$ & 0.046 & ARPC5, ARPC2, ARPC3 \\
\hline
\end{tabular}

When 102 trio families were genotyped for the ALOX5 6 bp GGGCGG deletion, TDT testing showed no evidence of transmission distortion for the deletion with 38 long (normal sequence): 34 short (deletion) transmitted ( $\mathrm{p}<$ 0.6). The short allele (minor allele) had a frequency of 0.19 in the MS population and 0.20 in the parental population. This deletion appears therefore not to be a significant risk factor in MS. We aimed to have the power to detect at least a 1.5- to 2-fold risk; however, a larger sample would be required for statistical power to detect a smaller risk factor. According to the McGinnis method, for trios, a 1.5 -fold risk requires 266 families for an $80 \%$ chance of detecting association at a $5 \%$ significance level whilst a 2-fold risk requires 85 families. Due to the small sample size no stratification was performed. Both the -557 SNPs were equally represented in the control and MS (DR+, DR-, Familial) pools, and so was not examined further [30]. 
Table 2: Dysregulated genes from patients in relapse and remission encoded in genomic regions associated with MS.

\begin{tabular}{|c|c|c|}
\hline $\begin{array}{l}\text { Chromosomal Region Associated with } \\
\text { MS }\end{array}$ & Genes Upregulated in Relapse & Genes Downregulated in Relapse \\
\hline $5 q 331$ & soX30 & 0 \\
\hline $17 q 231$ & FTSJ3, USP32, MRC2, TLK2, PRKARIA & SMARCD2, HANIIWD \\
\hline $19 p|3|$ & $\begin{array}{l}\text { CD97, HOMER3, THRAP5, ILF3, OAZI, AES, } \\
\text { FUTC, SAFB, CI } 9 \text { ORF6, ARHGEFI8, SF4, } \\
\text { GADD45B, CYP4FI2 }\end{array}$ & $\begin{array}{l}\text { RGSI 9IPI, DHPS, MGCII } 27 \text { I, KLFI, GCDH, } \\
\text { FLJ90396, AZUI, FARSLA, KHSRP, TRIPI0, } \\
\text { ILVBI, ANGPTL4, NDUB7, NDUFA, } \\
\text { MADCAMI7 }\end{array}$ \\
\hline I Iq23 (DI ISI 986) ${ }^{2}$ & 0 & 0 \\
\hline 19q13.2 (DI9S552) ${ }^{2}$ & TGFBI, CEACAMI, GMF & 0 \\
\hline $20 \mathrm{pl} 2$ (D20S894) 2 & 0 & 0 \\
\hline \multirow[t]{2}{*}{ IMSGC $^{3}$} & TAFIA & FHIT, DBCI \\
\hline & Genes Upregulated in Remission & Genes Downregulated in Remission \\
\hline $5 q 331$ & 0 & 0 \\
\hline $17 q 231$ & 0 & 0 \\
\hline |9p|31 & 0 & 0 \\
\hline IIq23 (DI ISI 986) ${ }^{2}$ & SDHD, CASPI, SIAT4C, APLP2 & $\begin{array}{l}\text { MGC2574, CD3E, RARRES3, CD3G, MTVRI, } \\
\text { PCSK7 }\end{array}$ \\
\hline $19 q 13.2(D \mid 9 S 552)^{2}$ & CEACAM4, VASP & PSG6, HNRPULI, PVR, EIF3SI 2 \\
\hline $20 \mathrm{pl} 2$ (D20S894) 2 & 0 & 0 \\
\hline IMSGC $^{3}$ & CD58 & FHIT \\
\hline
\end{tabular}

Chromosomal regions are those identified as associated by Sawcer et al (2005)' [27] from the family study or by the GAMES collaboration (2006) ${ }^{2}$ [26] using microsatellites (as marked) in a case/control study, and from the IMSGC SNP based genome wide analysis ${ }^{3}$ [10]. Genes are from the set of genes dysregulated in relapse and remission. Highlighted genes have been associated with MS in replication cohorts.

\section{Discussion}

Gene expression profiles of RRMS: relapse vs. remission

This study found a large number of dysregulated genes in peripheral blood during the relapse and remission phases of RRMS. When these sets of genes were compared against the total gene set contained on the array, there was a statistically significant over-representation of apoptosis- and inflammatory-related gene ontologies in the relapse upregulated gene set. This was expected as MS relapse is associated with detrimental inflammation in which increases in inflammatory cell activation and the activation of inflammatory-related pathways is predominant. Recent studies have also found upregulation of inflammatory anti-apoptotic pathways in relapse [6], as a distinct MS cluster [31], or in MS compared to controls [32-34]. This is also consistent with the success of immunomodulatory therapies in RRMS [35]. In the remission up-regulated gene set, there was an over-representation of protein transport and localization, and actin polymerisation ontologies. Since these processes are altered when cells change shape and motility, they may indicate that fluctuation in cell trafficking is important in remission.

To date, microarray studies using MS blood have focused on peripheral blood mononuclear cells. Recently, the involvement of other blood cells in MS disease pathogenesis, such as neutrophils, has raised interest due to increasing evidence suggesting that elements of the immune response classically associated with allergy, may contribute to the pathogenesis of autoimmune CNS demyelinating diseases, such as MS and its animal model EAE [36]. We have identified the upregulation, both during relapse and remission, of arachidonate 5-lipoxygenase (ALOX5), an enzyme that catalyzes the initial steps in the conversion of arachidonic acid to biologically active leukotrienes in neutrophils $[37,38]$. Interestingly, we previously found an up-regulation of ALOX5 in both secondary progressive and primary progressive MS patients [7]. Gene expression studies of MS and EAE lesions have also reported increased levels of ALOX5 [11] in addition to other allergy-related mediators [39-41].

\section{Gene promoter variation and expression}

Combining genomic and transcriptomic data has proved useful in identifying genetic associations in disease. In this way we earlier identified CD127 polymorphisms as associated with PPMS [7], an association now independently confirmed in two large cohorts $[8,9]$. The general principal of finding SNPs affecting expression in the 5' UTR region has also now been established by combining expression phenotype and HapMap data [4] or from the ENCODE project [5]. We have examined the putative promoter regions of TGF $\beta 1$ and ALOX5 for polymorphisms then tested the association of these variants with MS. A further advantage of this approach is that if promoter polymorphisms are associated with $\mathrm{MS}$, then this provides 
Table 3: Genetic variants in the putative ALOX5 and TGF $\beta$ I promoters.

\begin{tabular}{|c|c|c|c|}
\hline Gene & GenBank Accession no. & $\begin{array}{l}\text { Common SNPs in the } 5 \text { ' upstream } \\
\text { promoter region }\end{array}$ & SNPs found in this study \\
\hline \multirow[t]{2}{*}{$\begin{array}{l}\text { Arachidonate 5- Lipoxygenase } \\
\text { (ALOX5) }\end{array}$} & $\underline{\mathrm{H}} 5 \mathrm{I} 574$ & $\begin{array}{l}\text { rs 12762303: }-557 \mathrm{~T}>\mathrm{C} \text { (Hoshiko et al, } \\
\text { 1990) } \\
-458 \mathrm{~T}>\mathrm{C} \text { (ensembl database) }\end{array}$ & $\begin{array}{l}\text { Both identified in MS and control } \\
\text { cohorts }\end{array}$ \\
\hline & & $\begin{array}{l}\text { GGGCGG tandem repeat deletion: } \\
\text { Between - } 146 \text { and - I } 76 \text { (Hoshiko et } \\
\text { al,1990) } \\
\text { Between }-48 \text { and }-78 \text { (ensembl } \\
\text { database) }\end{array}$ & \\
\hline \multirow[t]{6}{*}{$\begin{array}{l}\text { Transforming growth factor beta-I } \\
\text { (TGF } \beta I \text { ) }\end{array}$} & $\underline{\mathrm{R} 364674}$ & $\begin{array}{l}\text { rs I2977628: }-18 \text { C>A (Kim et al, 1989) } \\
+|8| C>A \text { (ensembl database) }\end{array}$ & $\begin{array}{l}\text { rs } 1800469 \text { identified in MS and } \\
\text { control cohorts }\end{array}$ \\
\hline & & $\begin{array}{l}\text { rs I75। 6265: }-257 \text { A }>C \text { (Kim et al, } \\
\text { 1989) } \\
-59 A>C \text { (ensembl database) }\end{array}$ & \\
\hline & & $\begin{array}{l}\text { rs353।8502: }-315 \text { C>T (Kim et al, } \\
\text { 1989) } \\
-117 \text { C>T (ensembl database) }\end{array}$ & \\
\hline & & $\begin{array}{l}\text { rs35775330: -33I TT del (Kim et al, } \\
\text { 1989) } \\
\text { - I33 TT del (ensembl database) }\end{array}$ & \\
\hline & & $\begin{array}{l}\text { rs I I 4663 I4: }-448 \text { G>A (Kim et al, } \\
\text { 1989) } \\
-250 \text { G>A (ensembl database) }\end{array}$ & \\
\hline & & $\begin{array}{l}\text { rs |800469: }-508 T>C \text { (Kim et al, 1989) } \\
-310 T>C \text { (ensembl database) }\end{array}$ & \\
\hline
\end{tabular}

\footnotetext{
Sequencing of the $5^{\prime}$ upstream promoter region of pooled genomic DNA confirmed the presence of two common genetic variants in the ALOX5 promoter: rs $12762303 \mathrm{~T}>\mathrm{C}$ and a 6 bp deletion of the tandem repeat sequence GGGCGG, in addition to a single common SNP in the TGF $\beta$ I promoter: rs $1800469 \mathrm{~T}>\mathrm{C}$. Common SNPs and their positions in the 5' promoter region are shown according to nucleotide numbering in the ensembl database and by the authors who first described the promoter regions for ALOX5 (Hoshiko et al, 1990) [66] and TGF $\beta$ I (Kim et al, 1989) [48]. Pooled DNA sequencing only detects common polymorphisms (> 10-15\% of sample) [30].
}

support for the observed aberrant expression being pathogenic rather than homeostatic.

Genomic regions chosen for screening of dysregulated genes were based on the current largest genomic studies $[10,26,27]$. The genomic region from the affected family study was large, and this is reflected in the large number of genes selected using these criteria. Three genes were targeted from the more stringent criteria provided by the GAMES study [26], and TGF $\beta 1$ was selected for further study as it is the only one whose expression is confined to immune cells.

\section{Variations in the TGF $\beta$ I promoter region}

In addition to being close to the microsatellite in the GAMES meta analysis [26], in 19q13.2, in which TGF $\beta 1$ is encoded, this gene has been identified as being associated with MS susceptibility in other studies [42-47]. Dysregulated expression of TGF $\beta 1$ may have significant consequences in MS pathogenesis and potentially could be due to sequence variation in the TGF $\beta 1$ promoter region. Only one common SNP, $-508 \mathrm{~T}>\mathrm{C}$, was detected in the $500 \mathrm{bp}$ 5' UTR putative promoter sequence [48] (Table 3). From twin studies, Grainger et al [49] demonstrated TGF $\beta 1$ expression was under genetic control, and that the T allele is associated with higher expression. Two groups have studied the association of this SNP with MS [50,51]. We found evidence for an association when 102 trios were genotyped, and then increased the numbers to 388 trio families. This is well in excess of the number needed to have the statistical power to have an $80 \%$ chance of detecting a risk factor of 1.5 at the 0.05 significance level (212 families needed according to the McGinnis method). We identified a trend towards over-transmission of the T allele in MS in our patient cohort. We then tested the association in a second independent trio cohort, but found only non-significant over-transmission (Table 4).

Interestingly Green et al, in contrast to Weinshenker et al, found the wild-type $\mathrm{C}$ allele (or the "low-producer" genotype), which was under-transmitted in our study, was associated with a milder disease course. EAE and human drug response data suggest high TGF $\beta 1$ expression would be protective [52-56]. Green et al [50] also found strong linkage disequilibrium (LD) existing between the SNP at position -508 and the codon 10 SNP and partial LD with two other codon changing SNPs, which may result in an altered function of the translated protein, which may in turn be the cause of the association with susceptibility found in our study. Neither Green et al (2001), nor Wein- 
shenker et al (2001), found an association between the 508 SNP and MS susceptibility (Table 5). A final assessment of the significance of TGF $\beta 1$ as a risk factor will be possible after larger, multiple cohorts have been studied, with informed stratification for clinical parameters, and after testing of epistatic interactions.

TGF $\beta 1$ is a multifunctional growth factor with demonstrable immunosuppressive effects on a number of cells including B cells, CD4+ T cells (Th1 and Th2), CD8+ cytotoxic T lymphocytes, natural killer cells and macrophages [57] and has been recently been implicated as a key factor in the differentiation of Th17 and T regulatory cells [58]. The full significance of TGF $\beta 1$-mediated effects on immune responses is still incompletely understood, but have been implicated in MS pathogenesis, with some studies finding reduced TGF $\beta 1$ levels during a relapse and an increase during remission [59-62]. However, it has also been reported that TGF $\beta 1$ levels increase during remission and even more so during relapse and in progressive patients [63].

\section{Variations in the ALOX5 promoter region}

This study is the first to investigate the ALOX5 promoter variations in MS patients. We did not identify any association between the variant 5'UTR alleles and MS, suggesting that these insertion/deletion (in/del) variants in the Sp1/Egr-1 binding sites are not pathogenic in MS, and may not be the cause of the increased ALOX5 expression measured in MS patients by microarray analysis. However, extensive quantitative studies would be needed to confirm this. As mentioned previously, our small sample size does not exclude this in/del as an appreciable risk factor. It is possible that in MS, as found in asthma [64], these promoter variations may affect disease modification rather than disease susceptibility - an idea worthy of further investigation if ALOX5 inhibitors were considered for MS treatment.

Table 4: Genotyping of the TGF $\beta \mid-508$ T>C SNP ( $r$ | $\mid 800469)$ in 423 informative MS trio families.

\begin{tabular}{lcc}
\hline Group & T:C & P-value \\
\hline Westmead & I39T:115C & 0.13 \\
SMSGC & $88 T: 81 \mathrm{C}$ & $\mathrm{ns}$ \\
All (both cohorts) & $227 \mathrm{~T}: 196 \mathrm{C}$ & 0.13 \\
IMSGC[10] & C>T (I.I odds ratio) & 0.20 \\
\hline
\end{tabular}

The samples were stratified and both corrected and uncorrected $\mathrm{p}$ values were calculated to avoid type I and type II errors. There is a trend for over-transmission of the T allele in MS $(p<0.13)$, and an association in females ( uncorrected $<0.04), \mathrm{HLA}-\mathrm{DR}+\left(\mathrm{P}_{\text {uncorrected }}<0.0 \mathrm{I}\right)$, which was also found when data was combined from a second independent cohort (SMSGC), but was not significant after correction for multiple testing. However, the IMSGC transmission was in the reverse order, with $\mathrm{C}$ overtransmitted [10]. This was inferred from the transmission of rs224I7I4, which is in LD with rs 1800469.

\section{IMSGC whole genome analysis: genes in the dysregulated} set

Of the 38 genes implicated in MS susceptibility on the first screen in the recently published whole genome screen, four were in the dysregulated gene sets identified here (Table 2). Two of these four genes were further supported as associated with MS susceptibility in their replication study: CD58 and DBC1. CD58, in common with the most associated genes from that and other studies [8-10], IL7R $\alpha$ and IL2R $\alpha$, affects regulatory T cell (Treg) differentiation and proliferation. TGF $\beta 1$ is essential for Treg differentiation. The up-regulation of CD58 in remission is consistent with the evidence that the protective allele is associated with higher CD58 expression, and that CD58 promotes Treg differentiation. Gene expression and genotyping data therefore further implicate Tregs in MS pathogenesis. Notably, the two most associated genes from the IMSGC study, IL7R $\alpha$ and IL2R $\alpha$, were not detected as dysregulated in whole blood. DBC1 is anti-proliferative [65], so that the higher expression observed in remission is consistent with an immunosuppressive function.

\section{Conclusion}

We have reported the gene expression profiles of RRMS during the relapse and remission phases, identifying numerous dysregulated genes which may be specific to RRMS pathogenesis. Up-regulation of ALOX5 during relapse and remission and in progressive disease [7], suggests a role for this molecule in MS. Higher expression of ALOX5 in whole blood supports a possible role for neutrophils and allergic component in MS pathogenesis. A pathogenic outcome of high expression could be increased permeability of the blood brain barrier. No association of ALOX5 promoter polymorphisms with MS susceptibility was detected, but a much larger sample size would be needed to exclude it as an appreciable risk factor.

The interpretation of the up-regulation of TGF $\beta 1$ and it role in MS pathogenesis, is challenging. TGF $\beta 1$ has a multitude of functions and there is evidence to support both an immunosuppressive and a proinflammatory role for it in MS pathogenesis. However, we propose that the observed up-regulation of TGF $\beta 1$ during relapse may be in response to the proinflammatory state and is acting to promote Treg cell proliferation. This is consistent with the observed increase in expression of CD58 in remission, a gene now with strong support for association with MS. Genotyping of the C>T SNP identified in the promoter region of the TGF $\beta 1$ gene, revealed non-significant overtransmission of the T allele in MS. Additional studies in independent and larger cohorts stratified for these parameters are needed. Further study is appealing, as confirmation of any genetic association and its phenotypic effect 
Table 5: T allele frequencies of the TGF $\beta$ I -508 T>C SNP (rs I 800469) as found by this study (*) and other studies.

\begin{tabular}{|c|c|c|c|}
\hline \multicolumn{2}{|c|}{ T Allele Frequency } & \multirow[t]{2}{*}{ Population Studied } & \multirow[t]{2}{*}{ Reference } \\
\hline Disease & Control & & \\
\hline- & 0.31 & Healthy female twins & Grainger et al. (1999) [49] \\
\hline 0.33 & 0.31 & Prostate cancer & Ewart-Toland et al. (2004) [67] \\
\hline $\begin{array}{c}\text { Belgian: } 0.32 \\
\text { Canadian: } 0.32\end{array}$ & $\begin{array}{c}\text { Belgian: } 0.31 \\
\text { Canadian: } 0.32\end{array}$ & Abdominal aortic aneurysms & Ogata et al. (2005) [68] \\
\hline $\begin{array}{l}\text { All IBD: } 0.34 \\
\text { Crohn's disease: } 0.42 \\
\text { Ulcerative colitis: } 0.35\end{array}$ & 0.26 & Inflammatory bowel disease (IBD) - Crohn's disease and ulcerative colitis & Schulte et al. (200I) ${ }^{[69]}$ \\
\hline $0.28 \#$ & $0.29 \#$ & Multiple sclerosis & Green et al. (200I) [50] \\
\hline 0.29 & 0.27 & Multiple sclerosis & Weinshenker et al. (200I) [5I] \\
\hline 0.33 & 0.30 & Multiple sclerosis* & This study \\
\hline
\end{tabular}

\# Green et al [50] investigated the frequencies of TGF $\beta$ I haplotypes comprising of five biallelic polymorphisms, including two in the promoter region (one being the $-508 \mathrm{~T}>\mathrm{C}$ ) and three in coding regions. Three haplotypes: GTCGC; GTTGC; and GTCGC, each containing the T allele (bold) at position -508 had frequencies of $0.24,0.025$ and $0.018(0.28)$ in the controls and $0.25,0.019$, and $0.018(0.29)$ in the MS individuals with no significant difference between the two groups.

will define a pathogenic process and target for novel therapeutic interventions.

\section{Abbreviations}

MS - multiple sclerosis

CNS - central nervous system

RRMS - relapsing remitting multiple sclerosis

PPMS - primary progressive multiple sclerosis

TGF $\beta 1$ - transforming growth factor beta-1

ALOX5 - arachidonate 5-lipoxygenase

CD58 - leukocyte function antigen 3

DBC-1 - deleted in bladder cancer 1

CD127 - interleukin 7 receptor

FHIT - fragile histidine triad gene

TAF1A - transcription factor 1A

SNP - single nucleotide polymorphism

BBB - blood brain barrier

RT-PCR - real-time polymerase chain reaction

TDT - transmission disequilibrium test

\section{Competing interests}

The author(s) declare that they have no competing interests.

\section{Authors' contributions}

ATA carried out the microarray, RT-PCR and sequencing studies. ATA and CB carried out microarray data analysis. DRB and SMSGC performed the genotyping. PJA, GJS and DRB conceived of the study, participated in its design and supervised the study. JDP and RNSH recruited, and collected blood from, MS patients for the study. ATA and DRB drafted the manuscript. All authors read and approved the final manuscript.

\section{Acknowledgements}

We would like to thank all of the MS patients and healthy controls who kindly donated blood, all those who contributed to the establishment of the Westmead MS DNA bank used for the sequencing and genotyping, and Najwa Marmash for genotyping assistance. This work was funded by a grant-in-aid from the Trish MS Research Foundation (2003), the Australian MS Society (2004) and Australian NHMRC project grant 153990. Ariel Arthur was supported by an Australian Postgraduate Award and The Nerve Research Foundation of the University of Sydney.

\section{References}

I. Compston A, Coles A: Multiple sclerosis. Lancet 2002, 359:|22|-|23|.

2. McDonald I: Relapse, Remission, and Progression in Multiple Sclerosis. N Eng J Med 2000, 343:| |486-| 487.

3. Noseworthy JH, Lucchinetti C, Rodriguez M, Weinshenker BG: Multiple sclerosis. N Engl J Med 2000, 343:938-952.

4. Cheung VG, Spielman RS, Ewens KG, Weber TM, Morley M, Burdick $\mathrm{JT}$ : Mapping determinants of human gene expression by regional and genome-wide association. Nature 2005, 437:1365-1369.

5. Stranger BE, Forrest MS, Clark AG, Minichiello MJ, Deutsch S, Lyle R, Hunt S, Kahl B, Antonarakis SE, Tavare S, Deloukas P, Dermitzakis ET: Genome-wide associations of gene expression variation in humans. PLoS Genet 2005, I:e78.

6. Achiron A, Gurevich M, Friedman N, Kaminski N, Mandel M: Blood transcriptional signatures of multiple sclerosis: unique gene expression of disease activity. Ann Neurol 2004, 55:4I 0-4I7. 
7. Booth DR, Arthur AT, Teutsch SM, Bye C, Rubio J, Armati PJ, Pollard JD, Heard RN, Stewart GJ: Gene expression and genotyping studies implicate the interleukin 7 receptor in the pathogenesis of primary progressive multiple sclerosis. J Mol Med 2005, 83:822-830.

8. Zhang Z, Duvefelt K, Svensson F, Masterman T, Jonasdottir G, Salter $H$, Emahazion T, Hellgren D, Falk G, Olsson T, Hillert J, Anvret M: Two genes encoding immune-regulatory molecules (LAG3 and IL7R) confer susceptibility to multiple sclerosis. Genes Immun 2005, 6: I45-I52.

9. Gregory SG, Schmidt S, Seth P, Oksenberg JR, Hart J, Prokop A, Caillier S], Ban M, Goris A, Barcellos LF, Lincoln R, McCauley JL, Sawcer SJ, Compston DA, Dubois B, Hauser SL, Garcia-Blanco MA, PericakVance MA, Haines JL, Multiple Sclerosis Genetics Group: Interleukin 7 receptor alpha chain (IL7R) shows allelic and functional association with multiple sclerosis. Nat Genet 2007, 39(9): |083-9|. Epub 2007 Jul 29

10. International Multiple Sclerosis Genetics Consortium, Hafler DA, Compston A, Sawcer S, Lander ES, Daly MJ, De Jager PL, de Bakker PI, Gabriel SB, Mirel DB, Ivinson AJ, Pericak-Vance MA, Gregory SG, Rioux JD, McCauley JL, Haines JL, Barcellos LF, Cree B, Oksenberg JR, Hauser SL: Risk alleles for multiple sclerosis identified by a genomewide study. N Engl J Med 357(9):85I-62. 2007 Aug 30, Epub 2007 Jul 29

II. Whitney LW, Ludwin SK, McFarland HF, Biddison WE: Microarray analysis of gene expression in multiple sclerosis and EAE identifies 5-lipoxygenase as a component of inflammatory lesions. J Neuroimmunol 200 I, I 2 1:40-48.

12. Ban M, Sawcer SJ, Heard RN, Bennetts BH, Adams S, Booth D, Perich $V$, Setakis $E$, Compston A, Stewart G]: A genome-wide screen for linkage disequilibrium in Australian HLA-DRB I*I50I positive multiple sclerosis patients. I Neuroimmunol 2003, 143:60-64.

13. Barcellos LF, Klitz W, Field LL, Tobias R, Bowcock AM, Wilson R, Nelson MP, Nagatomi J, Thomson G: Association mapping of disease loci, by use of a pooled DNA genomic screen. Am J Hum Genet 1997, 61:734-747.

14. PAXgene Blood RNA Kit Handbook [http://www.preana lytix.com/pdf/RNA handbook.pdf]

15. MessageAmp II aRNA amplification Kit Manua [http:// www.ambion.com/techlib/prot/fm |75|.pdf]

16. Complete datasets for relapse and remission patients from this study [http://www.wmi.usyd.edu.au/ourpeople/profiles/ booth david.htm]

17. SuperScript Indirect cDNA Labelling System Manual [http:/ /www.invitrogen.com/content/sfs/manuals/ superscriptindirectcdnalabeling man.pdf]

18. Bioconductor (Limma program) [http://www.bioconduc
B. tor.org]

19. Significance Analysis of Microarrays (SAM) package [http:// www-stat.stanford.edu/ tibs/SAM/]

20. GOstat by Tim Beissbarth [http://gostat.wehi.edu.au/cgi-bin/goS tat.pl]

21. Rozen S, Skaletsky H: Primer3 on the WWW for general users and for biologist programmers. Methods Mol Biol 2000, 132:365-386.

22. Livak KJ, Schmittgen TD: Analysis of relative gene expression data using real-time quantitative PCR and the 2(-Delta Delta C(T)) Method. Methods 200I, 25:402-408.

23. Spielman RS, McGinnis RE, Ewens W]: Transmission test for link age disequilibrium: the insulin gene region and insulindependent diabetes mellitus (IDDM). Am J Hum Genet 1993, 52:506-516.

24. Barrett JC, Fry B, Maller J, Daly MJ: Haploview: analysis and visualization of LD and haplotype maps. Bioinformatics 2005, 21:263-265

25. Rubio JP, Bahlo M, Tubridy N, Stankovich J, Burfoot R, Butzkueven H, Chapman C, Johnson L, Marriott M, Mraz G, Tait B, Wilkinson C, Taylor B, Speed TP, Foote SJ, Kilpatrick TJ: Extended haplotype analysis in the HLA complex reveals an increased frequency of the HFE-C282Y mutation in individuals with multiple sclerosis. Hum Genet 2004, I | 4:573-580.

26. The Games Collaborative Group: Linkage disequilibrium screening for multiple sclerosis implicates JAGI and POU2AFI as susceptibility genes in Europeans. J Neuroimmunol 2006, 179: $108-116$.
27. Sawcer S, Ban M, Maranian M, Yeo TW, Compston A, Kirby A, Daly MJ, De Jager PL, Walsh E, Lander ES, Rioux JD, Hafler DA, Ivinson A, Rimmler J, Gregory SG, Schmidt S, Pericak-Vance MA, Akesson E, Hillert J, Datta P, Oturai A, Ryder LP, Harbo HF, Spurkland A, Myhr KM, Laaksonen M, Booth D, Heard R, Stewart G, Lincoln R, Barcellos LF, Hauser SL, Oksenberg JR, Kenealy SJ, Haines JL: A high-density screen for linkage in multiple sclerosis. Am J Hum Genet 2005, 77:454-467.

28. Abbas AR, Baldwin D, Ma Y, Ouyang W, Gurney A, Martin F, Fong $S$, van Lookeren CM, Godowski P, Williams PM, Chan AC, Clark HF: Immune response in silico (IRIS): immune-specific genes identified from a compendium of microarray expression data. Genes Immun 2005, 6:319-33I.

29. In KH, Asano K, Beier D, Grobholz J, Finn PW, Silverman EK, Silverman ES, Collins T, Fischer AR, Keith TP, Serino K, Kim SW, De Sanctis GT, Yandava C, Pillari A, Rubin P, Kemp J, Israel E, Busse W, Ledford D, Murray JJ, Segal A, Tinkleman D, Drazen JM: Naturally occurring mutations in the human 5-lipoxygenase gene promoter that modify transcription factor binding and reporter gene transcription. J Clin Invest 1997, 99: I |30- I I37.

30. Teutsch SM, Booth DR, Bennetts BH, Heard RN, Stewart GJ: Identification of I I novel and common single nucleotide polymorphisms in the interleukin-7 receptor-alpha gene and their associations with multiple sclerosis. Eur J Hum Genet 2003, I I:509-5I5.

31. van Baarsen LG, van der Pouw Kraan TC, Kragt J], Baggen JM, Rustenburg F, Hooper T, Meilof JF, Fero MJ, Dijkstra CD, Polman CH, Verweij CL: A subtype of multiple sclerosis defined by an activated immune defense program. Genes Immun 2006, 7:522-531.

32. Aune TM, Maas K, Moore JH, Olsen NJ: Gene expression profiles in human autoimmune disease. Curr Pharm Des 2003, 9:1905-1917.

33. Ramanathan M, Weinstock-Guttman B, Nguyen LT, Badgett D, Miller $C$, Patrick $K$, Brownscheidle $C$, Jacobs $L$ : In vivo gene expression revealed by cDNA arrays: the pattern in relapsing-remitting multiple sclerosis patients compared with normal subjects. Neuroimmunol 2001, 116:213-219.

34. Bomprezzi R, Ringner M, Kim S, Bittner ML, Khan J, Chen Y, Elkahloun A, Yu A, Bielekova B, Meltzer PS, Martin R, McFarland HF, Trent JM: Gene Expression Profile in Multiple Sclerosis Patients and Healthy Controls: Identifying Pathways Relevant to Disease. Hum Mol Genet 2003, I 2:2191-2199.

35. Frohman EM, Stuve O, Havrdova E, Corboy J, Achiron A, Zivadinov R, Sorensen PS, Phillips JT, Weinshenker B, Hawker K, Hartung HP, Steinman L, Zamvil S, Cree BA, Hauser S, Weiner H, Racke MK, Filippi M: Therapeutic considerations for disease progression in multiple sclerosis: evidence, experience, and future expectations. Arch Neurol 2005, 62:1519-1530.

36. Pedotti R, De Voss J], Steinman L, Galli S): Involvement of both 'allergic' and 'autoimmune' mechanisms in EAE, MS and other autoimmune diseases. Trends Immunol 2003, 24:479-484.

37. Samuelsson B: An elucidation of the arachidonic acid cascade. Discovery of prostaglandins, thromboxane and leukotrienes. Drugs 1987, 33(SuppI I):2-9.

38. Ford-Hutchinson AW, Gresser M, Young RN: 5-Lipoxygenase. Annu Rev Biochem 1994, 63:383-4I7.

39. Chabas D, Baranzini SE, Mitchell D, Bernard CC, Rittling SR, Denhardt DT, Sobel RA, Lock C, Karpuj M, Pedotti R, Heller R, Oksenberg JR, Steinman $L$ : The influence of the proinflammatory cytokine, osteopontin, on autoimmune demyelinating disease. Science 200I, 294: $1731-1735$.

40. Lock C, Hermans G, Pedotti R, Brendolan A, Schadt E, Garren H, Langer-Gould A, Strober S, Cannella B, Allard J, Klonowski P, Austin A, Lad N, Kaminski N, Galli SJ, Oksenberg JR, Raine CS, Heller R, Steinman L: Gene-microarray analysis of multiple sclerosis lesions yields new targets validated in autoimmune encephalomyelitis. Nat Med 2002, 8:500-508.

4I. Pedotti R, DeVoss J], Youssef S, Mitchell D, Wedemeyer J, Madanat R, Garren H, Fontoura P, Tsai M, Galli S], Sobel RA, Steinman L: Multiple elements of the allergic arm of the immune response modulate autoimmune demyelination. Proc Natl Acad Sci USA 2003, 100:1867-1872.

42. Barcellos LF, Thomson G, Carrington M, Schafer J, Begovich AB, Lin $\mathrm{P}, \mathrm{Xu} X \mathrm{H}$, Min BQ, Marti D, Klitz W: Chromosome 19 singlelocus and multilocus haplotype associations with multiple 
sclerosis. Evidence of a new susceptibility locus in Caucasian and Chinese patients. JAMA 1997, 278:1256-I26I.

43. Pericak-Vance MA, Rimmler JB, Martin ER, Haines JL, Garcia ME, Oksenberg JR, Barcellos LF, Lincoln R, Goodkin DE, Hauser SL: Linkage and association analysis of chromosome $19 q / 3$ in multiple sclerosis. Neurogenetics 200I, 3:195-20I.

44. Lucotte GL: Confirmation of a gene for multiple sclerosis (MS) to chromosome region I9q I3.3. Genet Couns 2002, I3: I 33-138.

45. Reunanen K, Finnila S, Laaksonen M, Sumelahti ML, Wikstrom J, Pastinen T, Kuokkanen S, Saarela J, Uimari P, Ruutiainen J, llonen J, Peltonen L, Tienari PJ: Chromosome 19q13 and multiple sclerosis susceptibility in Finland: a linkage and two-stage association study. J Neuroimmunol 2002, I 26: I34-142.

46. Haines JL, Bradford Y, Garcia ME, Reed AD, Neumeister E, PericakVance MA, Rimmler JB, Menold MM, Martin ER, Oksenberg JR, Barcellos LF, Lincoln R, Hauser SL: Multiple susceptibility loci for multiple sclerosis. Hum Mol Genet 2002, I I:225I-2256.

47. Pericak-Vance MA, Rimmler JB, Haines JL, Garcia ME, Oksenberg JR, Barcellos LF, Lincoln R, Hauser SL, Cournu-Rebeix I, Azoulay-Cayla A, Lyon-Caen O, Fontaine B, Duhamel E, Coppin H, Brassat D, Roth MP, Clanet M, Alizadeh M, Yaouanq J, Quelvennec E, Semana G, Edan G, Babron MC, Genin E, Clerget-Darpoux F: Investigation of seven proposed regions of linkage in multiple sclerosis: an American and French collaborative study. Neurogenetics 2004, 5:45-48.

48. Kim S], Glick A, Sporn MB, Roberts AB: Characterization of the promoter region of the human transforming growth factorbeta I gene. J Biol Chem 1989, 264:402-408.

49. Grainger DJ, Heathcote K, Chiano M, Snieder H, Kemp PR, Metcalfe JC, Carter ND, Spector TD: Genetic control of the circulating concentration of transforming growth factor type betal. Hum Mol Genet 1999, 8:93-97.

50. Green AJ, Barcellos LF, Rimmler JB, Garcia ME, Caillier S, Lincoln RR, Bucher P, Pericak-Vance MA, Haines JL, Hauser SL, Oksenberg JR: Sequence variation in the transforming growth factor-betal (TGFBI) gene and multiple sclerosis susceptibility. J Neuroimmunol 200I, I16:116-124.

5I. Weinshenker BG, Hebrink D, Kantarci OH, Schaefer-Klein J, Atkinson E, Schaid D, McMurray CM: Genetic variation in the transforming growth factor betal gene in multiple sclerosis. J Neuroimmunol 200I, I 20:138-145.

52. Racke MK, Dhib-Jalbut S, Cannella B, Albert PS, Raine CS, McFarlin $D E:$ Prevention and treatment of chronic relapsing experimental allergic encephalomyelitis by transforming growth factor-beta I. J Immunol |99I, | 46:30|2-30I7.

53. Racke MK, Cannella B, Albert P, Sporn M, Raine CS, McFarlin DE: Evidence of endogenous regulatory function of transforming growth factor-beta I in experimental allergic encephalomyelitis. Int Immunol 1992, 4:615-620.

54. Kulkarni $A B$, Karlsson $S$ : Transforming growth factor-beta knockout mice. A mutation in one cytokine gene causes a dramatic inflammatory disease. Am J Pathol 1993, 143:3-9.

55. Kulkarni AB, Huh CG, Becker D, Geiser A, Lyght M, Flanders KC, Roberts $A B$, Sporn MB, Ward JM, Karlsson S: Transforming growth factor beta I null mutation in mice causes excessive inflammatory response and early death. Proc Natl Acad Sci USA 1993, 90:770-774

56. Chen W, Wahl SM: Manipulation of TGF-beta to control autoimmune and chronic inflammatory diseases. Microbes Infect 1999, I:I367-1380.

57. Prud'homme G], Piccirillo CA: The inhibitory effects of transforming growth factor-beta-I (TGF-betal) in autoimmune diseases. J Autoimmun 2000, 14:23-42.

58. Bettelli E, Carrier Y, Gao W, Korn T, Strom TB, Oukka M, Weiner HL, Kuchroo VK: Reciprocal developmental pathways for the generation of pathogenic effector $\mathrm{TH} / 7$ and regulatory $\mathrm{T}$ cells. Nature 2006, 441:235-238.

59. Mokhtarian F, Shi Y, Shirazian D, Morgante L, Miller A, Grob D: Defective production of anti-inflammatory cytokine, TGFbeta by $\mathrm{T}$ cell lines of patients with active multiple sclerosis. J Immunol 1994, I 52:6003-60I0.

60. Rieckmann P, Albrecht M, Kitze B, Weber T, Tumani H, Broocks A Lüer W, Poser S: Cytokine mRNA levels in mononuclear blood cells from patients with multiple sclerosis. Neurology 1994, 44(8): $1523-1526$.
61. Rieckmann P, Albrecht M, Kitze B, Weber T, Tumani H, Broocks A Luer W, Helwig A, Poser S: Tumor necrosis factor-alpha messenger RNA expression in patients with relapsing-remitting multiple sclerosis is associated with disease activity. Ann Neurol 1995, 37:82-88.

62. Bertolotto A, Capobianco M, Malucchi S, Manzardo E, Audano L, Bergui $M$, Bradac GB, Mutani R: Transforming growth factor betal (TGFbetal) mRNA level correlates with magnetic resonance imaging disease activity in multiple sclerosis patients. Neurosci Lett 1999, 263:21-24.

63. Nicoletti F, Di Marco R, Patti F, Reggio E, Nicoletti A, Zaccone P, Stivala $F$, Meroni $P L$, Reggio A: Blood levels of transforming growth factor-beta I (TGF-betal) are elevated in both relapsing remitting and chronic progressive multiple sclerosis (MS) patients and are further augmented by treatment with interferon-beta Ib (IFN-beta I b). Clin Exp Immunol 1998, I I 3:96-99.

64. Drazen JM, Yandava CN, Dube L, Szczerback N, Hippensteel R, Pillari A, Israel E, Schork N, Silverman ES, Katz DA, Drajesk J: Pharmacogenetic association between ALOX5 promoter genotype and the response to anti-asthma treatment. Nat Genet 1999, 22:168-170.

65. Trauernicht AM, Kim SJ, Kim NH, Boyer TG: Modulation of estrogen receptor alpha protein level and survival function by DBC-I. Mol Endocrinol 2007, 2I(7): I526-36.

66. Hoshiko S, Radmark O, Samuelsson B: Characterization of the human 5-lipoxygenase gene promoter. Proc Natl Acad Sci USA 1990, 87:9073-9077.

67. Ewart-Toland A, Chan JM, Yuan J, Balmain A, Ma J: A gain of function TGFBI polymorphism may be associated with late stage prostate cancer. Cancer Epidemiol Biomarkers Prev 2004, 13:759-764.

68. Ogata T, Shibamura H, Tromp G, Sinha M, Goddard KA, Sakalihasan N, Limet R, MacKean GL, Arthur C, Sueda T, Land S, Kuivaniemi H: Genetic analysis of polymorphisms in biologically relevant candidate genes in patients with abdominal aortic aneurysms. J Vasc Surg 2005, 41:1036-1042.

69. Schulte CM, Goebell H, Roher HD, Schulte KM: C-509T polymorphism in the TGFBI gene promoter: impact on Crohn's disease susceptibility and clinical course? Immunogenetics 200I, 53:178- 182 .

\section{Pre-publication history}

The pre-publication history for this paper can be accessed here:

http://www.biomedcentral.com/1471-2350/9/17/prepub

Publish with BioMed Central and every scientist can read your work free of charge

"BioMed Central will be the most significant development for disseminating the results of biomedical research in our lifetime. "

Sir Paul Nurse, Cancer Research UK

Your research papers will be:

- available free of charge to the entire biomedical community

- peer reviewed and published immediately upon acceptance

- cited in PubMed and archived on PubMed Central

- yours - you keep the copyright
BioMedcentral 